Jurnal Tanah dan Air (Soil and Water Journal)

ISSN: 1411-5719(p): 2655-500X (e), Volume 16 Nomor 1 (Juni 2019): 34 - 42 (http://jurnal.upnyk.ac.id/index.php/ita/index)

\title{
ANALISIS KESESUAIAN LAHAN TANAMAN SIRSAK, SRIKAYA DAN LENGKENG DI DESA HARGOMULYO, GEDANGSARI, GUNUNGKIDUL
}

\author{
(ANALYSIS OF LAND SUITABILITY FOR SOURSOP, SWEETSOP AND \\ LONGAN IN HARGOMULYO VILLAGE, GEDANGSARI, GUNUNGKIDUL)
}

\author{
Vina Elviana Meilinda ${ }^{1)}$, M.Kundarto ${ }^{2 *)}$ dan AZ. Purwono Budi Santoso ${ }^{2)}$ \\ ${ }^{1)}$ Prodi Agroteknologi, Universitas Pembangunan Nasional Veteran Yogyakarta \\ ${ }^{2}$ Prodi Ilmu Tanah, Universitas Pembangunan Nasional Veteran Yogyakarta \\ ${ }^{*}$ Corresponding author E-mail: mkundarto@gmail.com
}

\begin{abstract}
Gedangsari district has planned for fruit's production located is Hargomulyo village. Planting fruit trees in Hargomulyo village is one of the method to utilize dry land. Plants cultivated are soursop, sweetsop and longan in Suruh, Jatibungkus and Mangli hamlets. The research purposes for knowing characteristics land and analysis land suitability plants soursop, sweetsop and longan in Hargomulyo village. Research used survey method for knowing field conditions and purposive method to determine sample points based on Land Mapping System. Land Mapping System made by overlaying land use map, slope map and soil map. Analysis land suitability used matching method based on land characteristics and land suitability. Parameter researched are temperature, rainfall, soil drainage, soil texture, rough material, effective depth, cation exchangeable capacity (CEC), base saturnation, soil potential of Hydrogen ( $\mathrm{pH}$ ), C-Organic, N-Total, phosfat available, potassium available, slope, erosion, surface rock, rock outcrops. Result class land suitability for plant soursop, sweetsop and longan are $\mathrm{S} 3_{\text {(1,rc,eh,oa) }} 2,0$ ha, $\mathrm{S} 3_{\text {(rc,eh,oa) }} 2,5 \mathrm{ha}, \mathrm{S} 3_{\text {(eh,oa,na) }} 9,9$ ha, $\mathrm{S} 3_{\text {(rc,eh) }}$ 8,9 ha, $\mathrm{S} 3_{\text {(rc) }} 70,6$ ha, $S 3_{(\text {eh) }} 4,4$ ha, $\mathrm{N}_{(\mathrm{lp}, \mathrm{rc}, \mathrm{eh})} 12,2 \mathrm{ha}, \mathrm{N}_{(\mathrm{lp}, \mathrm{rc})} 45,1$ ha, $\mathrm{N}_{(\mathrm{rc}, \mathrm{eh})} 11,6 \mathrm{ha}, \mathrm{N}_{\text {(rc) }} 22,7$ ha and $\mathrm{N}_{(\mathrm{eh})} 10,6$ ha.
\end{abstract}

Keywords: land characteristics, land suitability, soursop, sweetsop, longan

\begin{abstract}
ABSTRAK
Kecamatan Gedangsari direncanakan sebagai daerah penghasil tanaman buah yang berada di Desa Hargomulyo. Penanaman tanaman buah di Desa Hargomulyo merupakan salah satu cara untuk memanfaatkan lahan kering. Tanaman yang akan dibudidayakan yaitu tanaman sirsak, srikaya dan lengkeng di tiga dusun yaitu Dusun Suruh, Jatibungkus dan Mangli. Tujuan dari penelitian ini adalah untuk mengetahui karakteristik lahan dan menganalisis kesesuaian lahan tanaman sirsak, srikaya dan lengkeng di Desa Hargomulyo. Penelitian menggunakan metode survey untuk mengetahui kondisi wilayah, metode purposive sampling untuk penentuan titik sampel berdasarkan Peta Sistem Lahan yang dibuat dengan overlay peta tataguna lahan, peta jenis tanah dan peta kemiringan lereng. Analisis kesesuaian lahan dilakukan dengan metode pembandingan (matching) karakteristik lahan dengan kriteria kesesuaian lahan. Parameter penelitian yang digunakan yaitu temperatur udara, curah hujan, kondisi drainase, tekstur tanah, bahan kasar, kedalaman tanah, KPK tanah, kejenuhan basa, $\mathrm{pH} \mathrm{H}_{2} \mathrm{O}$, C-Organik, N-Total, $\mathrm{P}$ tersedia, $\mathrm{K}$ tersedia, kemiringan lereng, bahaya erosi, batuan di permukaan dan singkapan batuan. Hasil penilaian kelas kesesuaian lahan pada tanaman sirsak, srikaya dan lengkeng yaitu kelas $\mathrm{S} 3_{\text {(lp,rc,eh,oa) }}$ 2,0 ha, S3 (rc,eh,oa) 2,5 ha, $\mathrm{S} 3_{\text {(eh,oa,na) }} 9,9$ ha, $\mathrm{S} 3_{\text {(rc,eh) }} 8,9$ ha, $\mathrm{S} 3_{\text {(rc) }} 70,6$ ha, $\mathrm{S} 3_{\text {(eh) }} 4,4$ ha, $\mathrm{N}_{\text {(lp,rc,eh) }} 12,2$ ha, $\mathrm{N}_{(\mathrm{lp}, \mathrm{rc})} 45,1$ ha, $\mathrm{N}_{(\mathrm{rc}, \mathrm{eh})} 11,6$ ha, $\mathrm{N}_{(\mathrm{rc})} 22,7$ ha dan $\mathrm{N}_{(\mathrm{eh})} 10,6$ ha,
\end{abstract}

Kata kunci: karakteristik lahan, kesesuaian lahan, sirsak, srikaya, lengkeng 


\section{PENDAHULUAN}

Kesesuaian lahan adalah tingkat kecocokan suatu bidang lahan untuk suatu penggunaan tertentu (Rayes, 2007). Klasifikasi kesesuaian lahan yang digunakan mengacu pada Framework of Land Evaluation (FAO, 1976). Lahan diartikan sebagai lingkungan fisik yang terdiri atas iklim, relief, tanah, air dan vegetasi serta benda yang diatasnya sepanjang ada pengaruhnya terhadap penggunaan lahan, termasuk didalamnya hasil kegiatan manusia (FAO dalam Arsyad, 1989). Peta kesesuaian lahan adalah peta yang menggambarkan kecocokan (adaptability) suatu lahan untuk tipe penggunaan (jenis tanaman dan tingkat pengelolaan) tertentu (Rayes, 2007). Dusun Suruh, Jatibungkus dan Mangli terletak di Desa Hargomulyo, Kecamatan Gedangsari, Kabupaten Gunungkidul memiliki jenis tanah entisol, inseptisol dan vertisol. Kondisi kemiringan lereng berkisar 0-54\%, namun beberapa lokasi sudah dilakukan konservasi lahan berupa pembuatan teras. Penggunaan lahan di lokasi penelitian berupa sawah, pemukiman, kebun, semak belukar dan didominasi oleh tegalan. Kebutuhan air untuk kegiatan pertanian hanya mengandalkan dari air hujan, sehingga ketika keterbatasan jumlah air ketika musim kemarau. Tanaman sirsak, srikaya dan lengkeng memiliki karakteristik lahan yang hampir sama seperti penanaman pada ketinggian 100 - 1.000 mdpl, kebutuhan curah hujan 1.500 - $3.000 \mathrm{~mm} /$ tahun, serta menghendaki $\mathrm{pH}$ tanah 5,5-7 (Sunarjono, 2008). Penelitian ini bertujuan untuk menentukan kelas kesesuaian lahan tanaman sirsak, srikaya dan lengkeng. di Dusun Suruh, Jatibungkus dan Mangli, Desa Hargomulyo,Kecamatan Gedangsari, Kabupaten Gunungkidul.

\section{BAHAN DAN METODE}

Penelitian berlokasi di Desa Hargomulyo, Kecamatan Gedangsari, Kabupaten Gunungkidul.

Alat : Bor, GPS, spektrofotometer, flamefotometer, buret, tabung sedimentasi, timbangan, gelas ukur, labu destilasi, erlenmeyer, dsb.

Bahan : Peta Jenis Tanah, Peta Tata Guna Lahan, Peta Kemiringan Lereng, Peta Sistem Lahan, sampel tanah, kemikalia, dan data curah hujan.

Penelitian ini dilakukan dengan menggunakan metode survei, yaitu metode pengumpulan data untuk mendapatkan keterangan dengan melakukan peninjauan serta pengamatan langsung di lapangan tempat penelitian. Pengambilan sampel dilakukan dengan menggunakan metode purposive sampling, yaitu penentuan titik sampel berdasarkan Peta Sistem Lahan yang merupakan hasil overlay dari Peta Jenis Tanah, Peta Tata Guna Lahan dan Peta Kemiringan Lereng. Analisis data menggunakan metode matching antara karakteristik lahan dengan tabel kelas kesesuaian lahan. Adapun tahapan penelitian sebagai berikut:

1. Tahap Persiapan

a. Kajian pustaka yang memiliki keterkaitan dengan penelitian

b. Pengumpulan peta tematik

c. Persiapan pembuatan Peta Sistem Lahan yang berasal dari overlay beberapa peta tematik, yaitu: peta jenis tanah, peta tata guna lahan, dan peta kemiringan lereng

2. Tahap Pelaksanaan

a. Pengambilan sampel tanah sebanyak 16 titik sampel. 
b. Pengamatan di lapangan

c. Pengumpulan data sekunder (Data dari BMKG)

d. Analisis laboratorium

Analisis Kesesuaian Lahan dengan menggunakan metode matching antara tabel karakteristik lahan dengan kelas kesesuaian lahan berdasarkan Balai Besar Sumberdaya Lahan Pertanian (2011). Hasil penilaian kelas kesesuaian lahan berdasarkan nilai terburuk dari nilai karakteristik lahan. Penulisan kelas kesesuaian lahan sampai tingkat subkelas, dengan menuliskan simbol karakteristik lahan yang menjadi faktor pembatas setelah nilai kelas kesesuaian lahan contoh $\mathrm{N}_{\mathrm{rc}, \mathrm{lp}}$. Usaha perbaikan dapat dilakukan untuk memperbaiki kelas kesesuaian lahan, namun terdapat beberapa karakteristik lahan tidak dapat dilakukan perbaikan. Usaha perbaikan lahan yang digunakan berdasarkan Hardjowigeno dan Widiatmaka (2011). Karakteristik lahan yang tidak dapat dilakukan perbaikan diantaranya pada faktor pembatas media perakaran dan penyiapan lahan.

\section{HASIL DAN PEMBAHASAN}

Tabel 1. Karakteristik Lahan yang digunakan dalam Analisis Lahan untuk Komoditas Pertanian.

\begin{tabular}{|c|c|c|}
\hline No & $\begin{array}{l}\text { Karakteristik } \\
\text { Lahan }\end{array}$ & Uraian \\
\hline 1 & $\begin{array}{l}\text { Temperatur rata- } \\
\text { rata tahunan }\end{array}$ & Suhu udara rata-rata tahunan $\left({ }^{\circ} \mathrm{C}\right)$ \\
\hline 2 & Curah hujan & $\begin{array}{l}\text { Jumlah curah hujan tahunan atau curah hujan pada masa } \\
\text { pertumbuhan (mm) }\end{array}$ \\
\hline 3 & Drainase & $\begin{array}{l}\text { Merupakan pengaruh laju perkolasi air ke dalam tanah } \\
\text { terhadap aerasi udara dalam tanah }\end{array}$ \\
\hline 4 & Tekstur & $\begin{array}{l}\text { Perbandingan butir-butir pasir }(0,05-2,0 \mathrm{~mm}), \text { debu }(0,002-0,05 \\
\text { mm) dan lempung }(<0,002 \mathrm{~mm})\end{array}$ \\
\hline 5 & Bahan kasar & Bahan yang berukuran $>2 \mathrm{~mm}(\%)$ \\
\hline 6 & $\begin{array}{l}\text { Kedalaman } \\
\text { efektif }\end{array}$ & $\begin{array}{l}\text { Kedalaman lapisan tanah yang dapat dimanfaatkan untuk } \\
\text { perkembangan perakaran tanaman }(\mathrm{cm})\end{array}$ \\
\hline 7 & KPK tanah & $\begin{array}{l}\text { Kemampuan tanah mempertukarkan kation (me/100 gram } \\
\text { tanah) }\end{array}$ \\
\hline 8 & $\begin{array}{l}\text { Kejenuhan Basa } \\
(\mathrm{KB})\end{array}$ & $\begin{array}{l}\text { Jumlah basa-basa terekstrak } \mathrm{NH}_{4} \mathrm{OAC} \text { pada setiap } 100 \text { gram contoh } \\
\text { tanah }\end{array}$ \\
\hline 9 & $\mathrm{pH}$ tanah & $\begin{array}{l}\text { Merupakan }\left[\mathrm{H}^{+}\right] \text {di dalam larutan tanah, semakin tinggi }\left[\mathrm{H}^{+}\right] \text {, maka } \\
\text { nilai pH semakin masam, sebaliknya semakin rendah }\left[\mathrm{H}^{+}\right] \text {, maka pH } \\
\text { semakin basis }\end{array}$ \\
\hline 10 & C-Organik & Kandungan karbon organik di dalam tanah $(\%)$ \\
\hline 11 & N Total & Total kandungan $\mathrm{N}$ dalam tanah (\%) \\
\hline 12 & $\mathrm{P}_{2} \mathrm{O}_{5}$ & $\begin{array}{l}\text { Kandungan } \mathrm{P}_{2} \mathrm{O}_{5} \text { terekstrak } \mathrm{HCl} 25 \% \text { dalam tanah }(\mathrm{mg} / 100 \text { gram } \\
\text { tanah) }\end{array}$ \\
\hline 13 & $\mathrm{~K}_{2} \mathrm{O}$ & $\begin{array}{l}\text { Kandungan } \mathrm{K}_{2} \mathrm{O} \text { terekstrak } \mathrm{HCl} 25 \% \text { dalam tanah (mg/100 } \\
\text { gram tanah) }\end{array}$ \\
\hline 15 & Lereng & Kemiringan lahan (\%) \\
\hline 16 & $\begin{array}{l}\text { Batuan di } \\
\text { permukaan }\end{array}$ & Volume batuan yang dijumpai di permukaan tanah (\%) \\
\hline 17 & Singkapan batuan & Volume batuan yang muncul ke permukaan tanah (\%) \\
\hline 18 & Bahaya erosi & Jumlah tanah hilang dari suatu lahan \\
\hline
\end{tabular}

Sumber: Balai Besar Penelitian dan Pengembangan Sumberdaya Lahan Pertanian (2011). 
J. Tanah dan Air, Vol. 16, No. 1, 2019: $34-42$

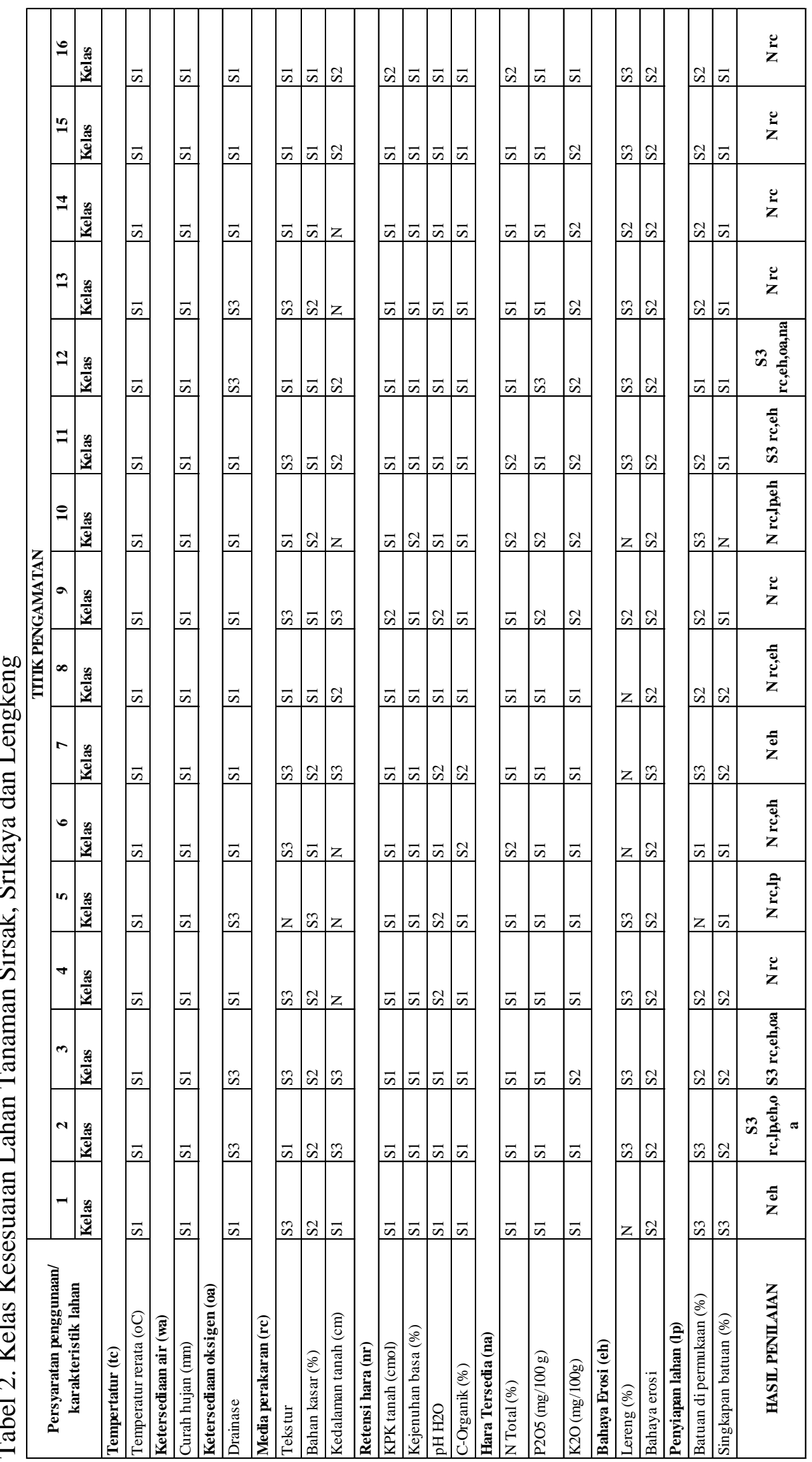




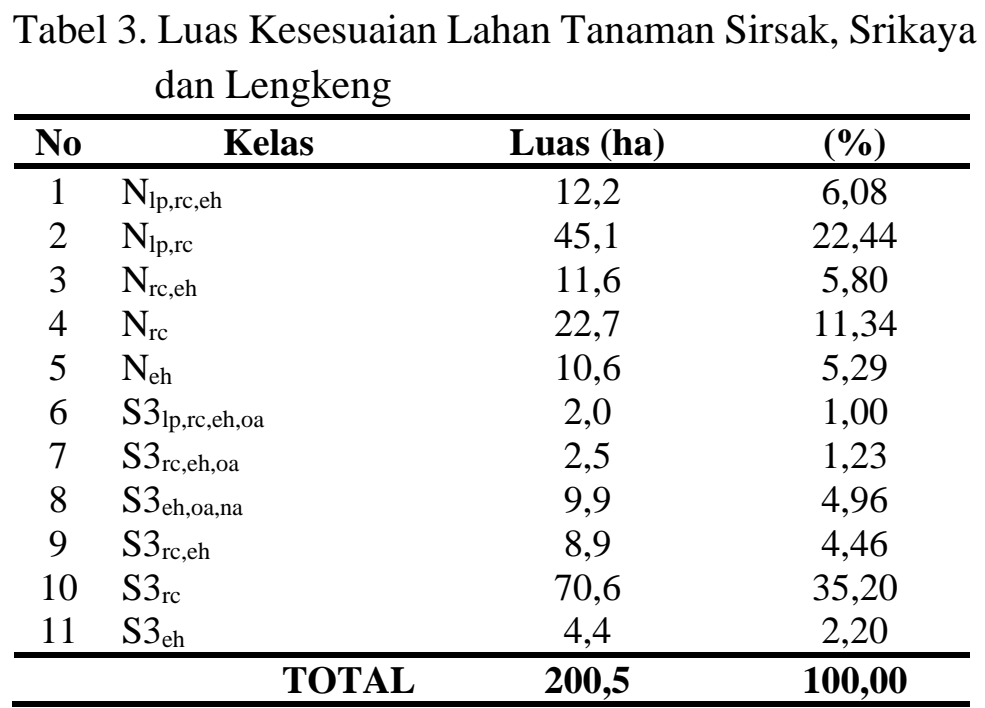

Hasil analisis kesesuaian lahan aktual untuk tanaman sirsak, srikaya dan lengkeng adalah tergolong kedalam 11 kelas. Untuk kelas kesesuaian lahan N (tidak sesuai) seluas 102,2 ha sedangkan untuk kelas kesesuaian lahan S3 (sesuai marginal) seluas 98,3 ha. Umumnya kelas kesesuaian lahan aktual untuk tanaman sirsak, srikaya adalah $\mathrm{S} 3$ rc atau kelas tidak sesuai dengan faktor pembatas media perakaran dengan luasan 70,6 ha yang merupakan $35,20 \%$ bagian dari luasan kesesuaian lahan tanaman srikaya.

Tabel 4. Jenis Usaha Perbaikan Kualitas/ Karakteristik Lahan Menurut Tingkat Pengelolaannya

\begin{tabular}{|c|c|c|c|}
\hline No & $\begin{array}{l}\text { Kualitas/ } \\
\text { Karakteristik Lahan }\end{array}$ & Jenis Usaha Perbaikan & $\begin{array}{l}\text { Tingkat } \\
\text { Pengelolaan }\end{array}$ \\
\hline 1. & $\begin{array}{l}\text { Media perakaran (rc) } \\
\text { - Drainase } \\
\text { - Tekstur } \\
\text { - Bahan Kasar } \\
\text { - Kedalaman efektif }\end{array}$ & $\begin{array}{l}\text { Perbaikan sistem drainase, seperti pembuatan saluran } \\
\text { drainase } \\
\text { Tidak dapat dilakukan } \\
\text { Tidak dapat dilakukan } \\
\text { Umumnya tidak dapat dilakukan, kecuali pada lapisan } \\
\text { padas lunak dan tipis dengan membongkarnya waktu } \\
\text { pengolahan tanah }\end{array}$ & Sedang, tinggi \\
\hline 2. & $\begin{array}{l}\text { Ketersediaan hara (na) } \\
\text { - } \mathrm{N} \text { Total } \\
-\mathrm{K}_{2} \mathrm{O} \\
-\mathrm{P}_{2} \mathrm{O}_{5}\end{array}$ & Pemupukan & $\begin{array}{l}\text { Rendah, sedang, } \\
\text { tinggi }\end{array}$ \\
\hline 3. & Bahaya erosi (eh) & $\begin{array}{l}\text { Usaha pengurangan laju erosi, pembuatan teras, } \\
\text { penanaman sejajar kontur, penanaman penutup tanah }\end{array}$ & Sedang, tinggi \\
\hline 4. & $\begin{array}{l}\text { Penyiapan lahan (lp) } \\
\text { - Batuan di permukaan } \\
\text { - Singkapan batuan }\end{array}$ & Tidak dapat dilakukan & \\
\hline
\end{tabular}

Sumber: Hardjowigeno dan Widiatmaka, 2011.

Keterangan:

- Tingkat pengelolaan rendah : pengelolaan dapat dilaksanakan oleh petani dengan biaya yang relatif

- Tingkat pengelolaan sedang : pengelolaan dapat dilaksanakan pada tingkat petani menengah memerlukan modal menengah dan teknik pertanian sedang

- Tingkat pengelolaan tinggi : pengelolaan hanya dapat dilaksanakan dengan modal yang relatif besar, umumnya dilakukan oleh pemerintah atau Perusahaan besar atau menengah 


\section{PETA KESESUAIAN LAHAN TANAMAN SRIKAYA DESA HARGOMULYO KECAMATAN GEDANGSARI KABUPATEN GUNUNGKIDUL}

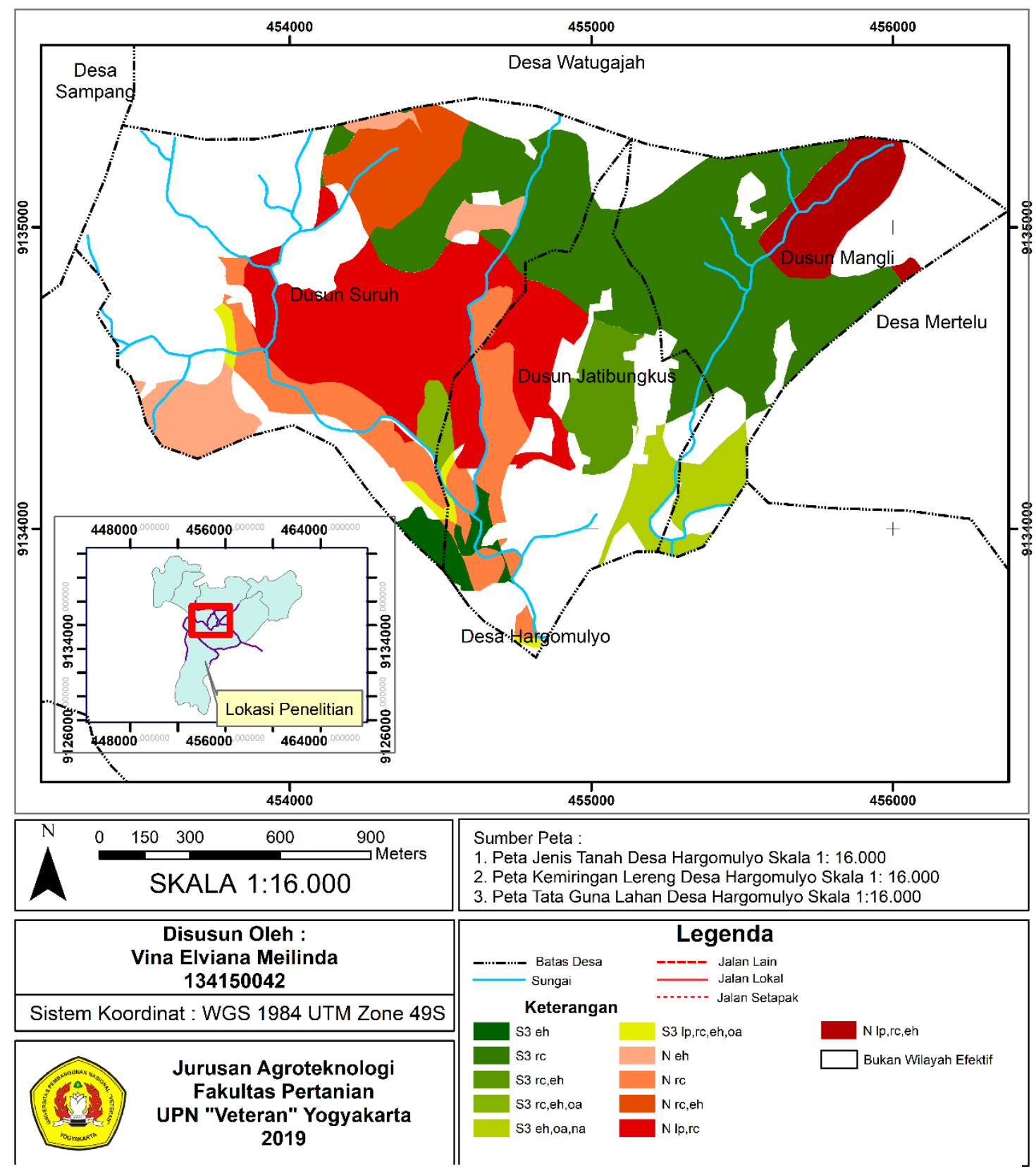

Gambar 1. Peta Kesesuaian Lahan Tanaman Srikaya, Desa Hargomulyo, Kecamatan Gedangsari, Gunungkidul 

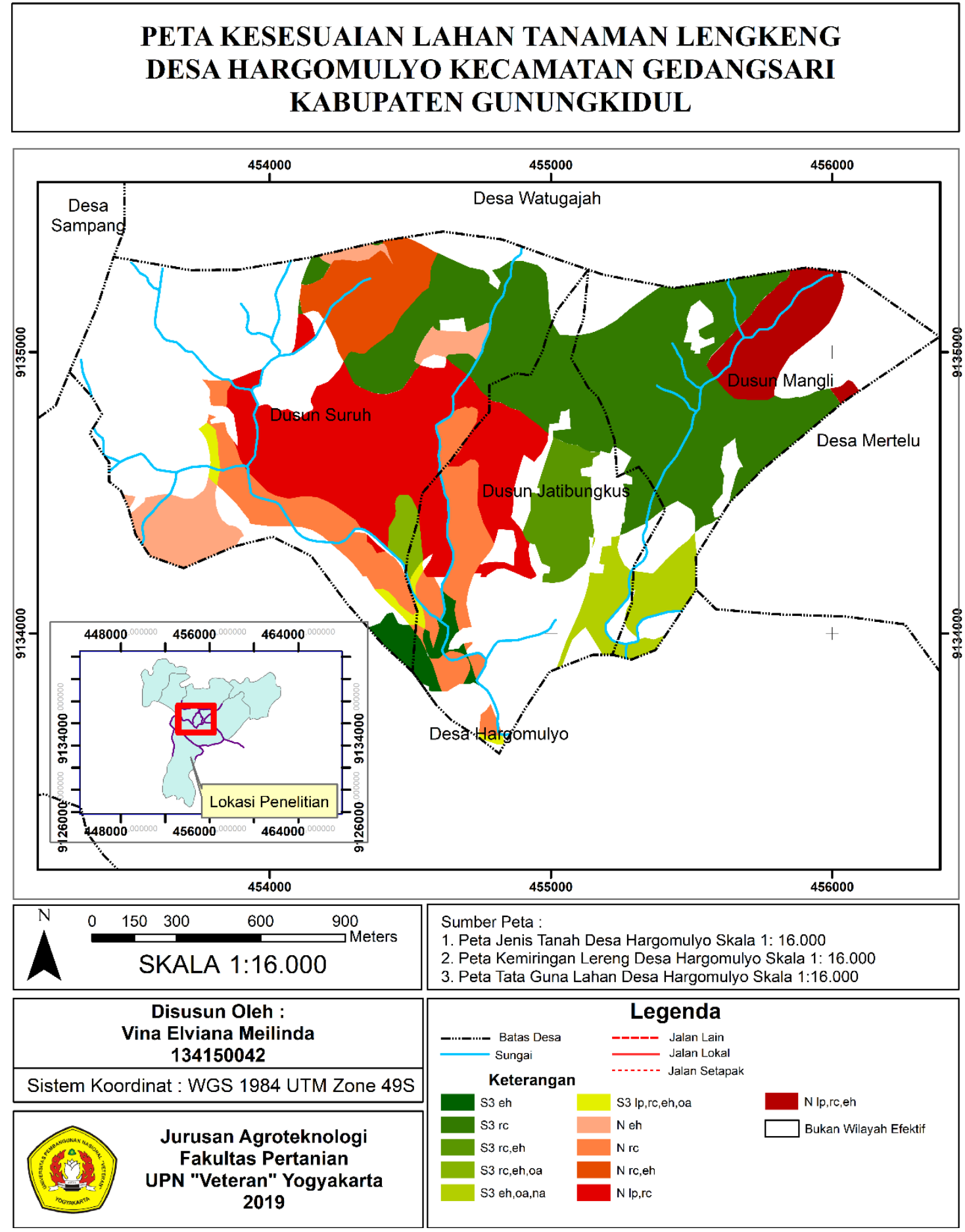

Gambar 2. Peta Kesesuaian Lahan Tanaman Lengkeng, Desa Hargomulyo, Kecamatan Gedangsari, Gunungkidul 

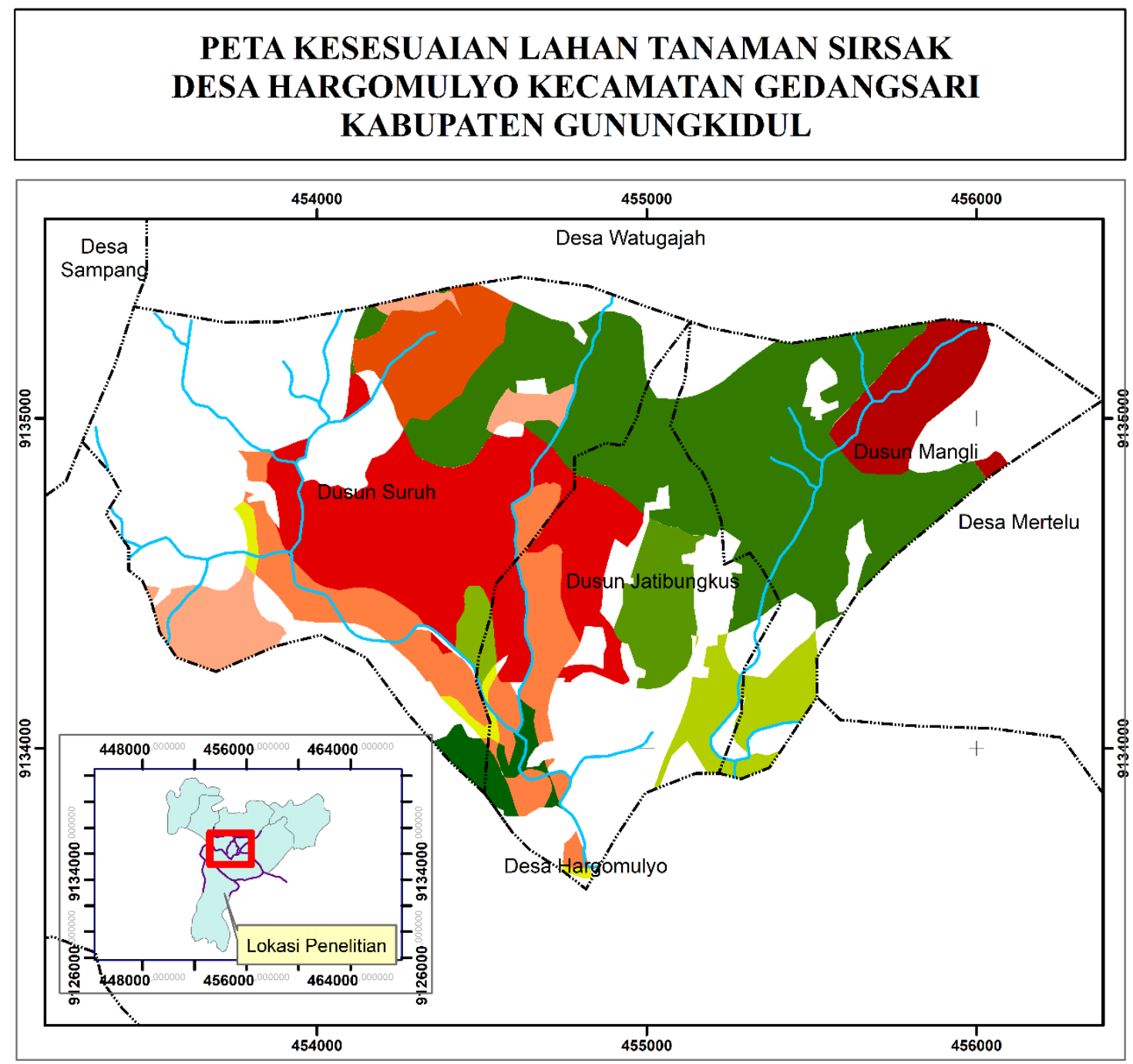

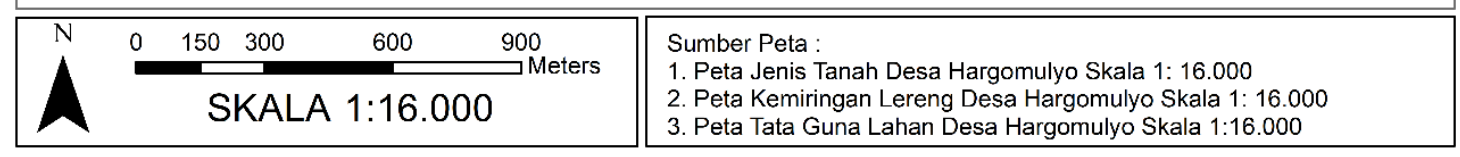

\begin{tabular}{|c|c|c|c|}
\hline $\begin{array}{c}\text { Disusun Oleh : } \\
\text { Vina Elviana Meilinda } \\
134150042 \\
\end{array}$ & $\begin{array}{l}-\cdots-\cdots-\text { Batas Desa } \\
- \text { Sungai }\end{array}$ & $\begin{array}{c}\text { Legenda } \\
--- \\
\\
\end{array}$ & \\
\hline Sistem Koordinat : WGS 1984 UTM Zone 49S & $\begin{array}{l}\text { Keterangan } \\
\mathrm{s} 3 \text { eh }\end{array}$ & S3 Ip,rc,eh,oa & N Ip, rc,eh \\
\hline $\begin{array}{l}\text { Jurusan Agroteknologi } \\
\text { Fakultas Pertanian } \\
\text { UPN "Veteran" Yogyakarta } \\
2019\end{array}$ & $\begin{array}{l}\text { S3 rc } \\
\text { S3 rc,eh } \\
\text { S3 rc,eh,oa } \\
\text { S3 eh,oa,na }\end{array}$ & $\begin{array}{l}\text { N eh } \\
N \text { rc } \\
N \text { rc,eh } \\
N \text { ip,rc }\end{array}$ & Bukan Wilayah Efektif \\
\hline
\end{tabular}

Gambar 3. Peta Kesesuaian Lahan Tanaman Sirsak, Desa Hargomulyo, Kecamatan Gedangsari, Gunungkidul 


\section{KESIMPULAN}

Kesimpulan dari penelitian ini yaitu kelas kesesuaian lahan tanaman sirsak, srikaya dan lengkeng memiliki kelas yang sama yaitu $\mathrm{S} 3_{\text {(lp,rceh,oa) }} 2,0$ ha, $\mathrm{S} 3_{\text {(rc,eh,oa) }} 2,5$ ha, $\mathrm{S} 3_{\text {(eh,oa,na) }}$ 9,9 ha, S3(rc,eh) 8,9 ha, S3(rc) 70,6 ha, S3 (eh) 4,4 ha, $\mathrm{N}_{(\mathrm{lp}, \mathrm{rc}, \mathrm{eh})} 12,2$ ha, $\mathrm{N}_{(\mathrm{lp}, \mathrm{rc})} 45,1$ ha, $\mathrm{N}_{(\mathrm{rc}, \mathrm{eh})} 11,6 \mathrm{ha}, \mathrm{N}_{(\mathrm{rc})} 22,7$ ha, dan $\mathrm{N}_{(\mathrm{eh})} 10,6$ ha. Usaha perbaikan yang dapat dilakukan oleh warga Desa Hargomulyo yaitu dengan membuat teras sebagai bentuk konservasi dan dilakukan pemupukan guna memenuhi kebutuhan unsur hara yang dibutuhkan dan memperbaiki sifat fisik dan kimia tanah.

\section{DAFTAR PUSTAKA}

Arsyad, S. 1989. Konservasi Tanah dan Air. IPB Press. Bogor.

Balai Besar Penelitian dan Pengembangan Sumberdaya Lahan. 2011. Petunjuk Teknis Evaluasi Lahan untuk Komoditas Pertanian. Bogor. Balai Besar Penelitian dan Pengembangan Sumberdaya Lahan Pertanian, Badan Penelitian dan Pengembangan Pertanian, Bogor. 166 hal.

FAO. 1976. A Framework for Land Evaluation. Soil Resources Management and Conservation Service Land and Water Development Division. FAO Soil Bulletin No.32. FAO-UNO. Rome.

Hardjowigeno, S dan Widiatmaka. 2011. Evaluasi Kesesuaian Lahan dan Perencanaan Tata Guna Lahan. Yogyakarta: Gadjah Mada University Press.

Rayes, M. L. 2007. Metode Inventarisasi Sumber Daya Lahan. Penerbit Andi, Yogyakarta.

Sunarjono, H.H. 2008. Berkebun 21 Jenis Tanaman Buah. Jakarta: Penebar Swadaya. 